\title{
Front Matter: Volume 11673
}

, "Front Matter: Volume 11673," Proc. SPIE 11673, Laser Applications in Microelectronic and Optoelectronic Manufacturing (LAMOM) XXVI, 1167301 (27 April 2021); doi: 10.1117/12.2596698

SPIE. Event: SPIE LASE, 2021, Online Only 


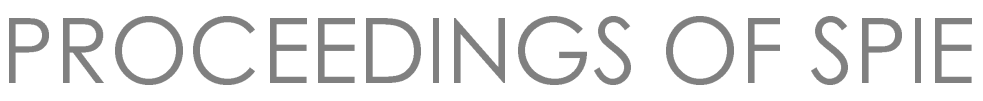

\section{Laser Applications in Microelectronic and Optoelectronic Manufacturing (LAMOM) XXVI}

\section{Carlos Molpeceres}

Jie Qiao

Aiko Narazaki

Editors

6-11 March 2021

Online Only, United States

Sponsored by

Okamoto Optics Works (Japan)

Plymouth Grating Laboratory (United States)

Published by

SPIE

Volume 11673 
The papers in this volume were part of the technical conference cited on the cover and title page. Papers were selected and subject to review by the editors and conference program committee. Some conference presentations may not be available for publication. Additional papers and presentation recordings may be available online in the SPIE Digital Library at SPIEDigitallibrary.org.

The papers reflect the work and thoughts of the authors and are published herein as submitted. The publisher is not responsible for the validity of the information or for any outcomes resulting from reliance thereon.

Please use the following format to cite material from these proceedings:

Author(s), "Title of Paper," in Laser Applications in Microelectronic and Optoelectronic Manufacturing (LAMOM) XXVI, edited by Carlos Molpeceres, Jie Qiao, Aiko Narazaki, Proc. of SPIE 11673, Seven-digit Article CID Number (DD/MM/YYYY); (DOI URL).

ISSN: 0277-786X

ISSN: 1996-756X (electronic)

ISBN: 9781510641815

ISBN: 9781510641822 (electronic)

Published by

SPIE

P.O. Box 10, Bellingham, Washington 98227-0010 USA

Telephone +1 3606763290 (Pacific Time)

SPIE.org

Copyright @ 2021 Society of Photo-Optical Instrumentation Engineers (SPIE).

Copying of material in this book for internal or personal use, or for the internal or personal use of specific clients, beyond the fair use provisions granted by the U.S. Copyright Law is authorized by SPIE subject to payment of fees. To obtain permission to use and share articles in this volume, visit Copyright Clearance Center at copyright.com. Other copying for republication, resale, advertising or promotion, or any form of systematic or multiple reproduction of any material in this book is prohibited except with permission in writing from the publisher.

Printed in the United States of America by Curran Associates, Inc., under license from SPIE.

Publication of record for individual papers is online in the SPIE Digital Library.

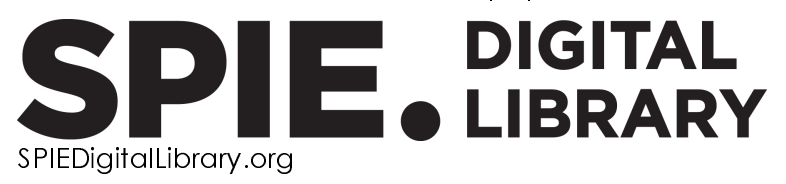

Paper Numbering: A unique citation identifier (CID) number is assigned to each article in the Proceedings of SPIE at the time of publication. Utilization of CIDs allows articles to be fully citable as soon as they are published online, and connects the same identifier to all online and print versions of the publication. SPIE uses a seven-digit CID article numbering system structured as follows:

- The first five digits correspond to the SPIE volume number.

- The last two digits indicate publication order within the volume using a Base 36 numbering system employing both numerals and letters. These two-number sets start with 00, 01, 02, 03, 04, 05, 06, 07, 08, 09, OA, OB ... 0Z, followed by 10-1Z, 20-2Z, etc. The CID Number appears on each page of the manuscript. 


\section{Contents}

\section{AI AND NEW TRENDS IN INDUSTRIAL ULTRAFAST PROCESSING}

1167303 Prediction of ultrashort pulse laser ablation processing using machine learning (Invited Paper) [11673-1]

$1167305 \quad$ High laser power resistance phase-only spatial light modulator for laser processing cyberphysical system [1 1673-3]

1167306 Estimation of the mobility of low temperature polycrystalline silicon thin film transistors through deep learning [11673-4]

OPTIMIZATION OF ENERGY DELIVERY IN ULTRAFAST PROCESSING

$1167308 \quad$ Ultrafast laser machining: process optimization and applications (Invited Paper) [11673-6]

$116730 \mathrm{~A} \quad$ Optimized temporal energy deposition for advanced processing of Si and SiC based on highly flexible TruMicro series 2000 [1 $1673-8]$

\section{ADVANCES IN GLASS PROCESSING}

$116730 \mathrm{D}$ Laser-fabricated axicons as an alternative to conventional optics for glass dicing (Invited Paper) [1 1673-11]

$11673 \mathrm{OH} \quad$ Inscription in the glass of efficient Gauss to top-hat converters based on Pancharatnam-Berry phase by high power femtosecond laser pulses [1 1673-15]

WELDING AND CUTTING WITH ULTRAFAST LASERS

11673 OK Welding with ultrashort laser pulses: recent developments at TRUMPF [11673-18]

FUNDAMENTALS

1167300 Dynamics of titanium ablation suppression induced by below-ablation-threshold femtosecond laser pulse irradiation [1 1673-22]

$116730 Q \quad$ Analytical model of time-dependent photoionization and nonlinear absorption of few-cycle laser pulses in dielectrics [1 1673-24] 
NANOSCALE MATERIAL PROCESSING IN ELECTRONICS

11673 OS Functional surface formation by efficient laser ablation using single-pulse and burst-modes [1 1673-26]

11673 OU Mid-infrared free electron laser induced periodic surface structures on semiconductors (Best Student Paper Award) [1 1673-28]

\section{INTEGRATION OF DEVICES}

$116730 \mathrm{~W} \quad$ Advancing integrated photonics and microreactor technologies with ultrafast laser processing (Invited Paper) [1 1673-30]

11673 0X Laser induced forward transfer of solder paste for microelectronics assembly applications [1 1673-31]

11673 OY Microprocessing machinability of organic material for semiconductor packaging by $248 \mathrm{~nm}$ excimer laser [1 1 673-32]

\section{NEW PROCESSES FOR ELECTRONICS, PHOTONICS AND PV}

1167315 Simulation of transference regimes in BA-LIFT of water-glycerol and LIFT of high-viscosity silver pastes (Invited Paper) [1 1673-39]

1167317 Direct laser writing of graded-index SiGe waveguides via phase segregation [1 1673-41]

$1167319 \quad$ Ultra-short pulses at high average power in the Laser MicroJet [1 1673-43]

\section{POSTER SESSION}

11673 1B High-speed observation of damage generation during ultrashort pulse laser drilling of widebandgap materials [1 $1673-45]$

11673 1C Influence of ambient pressure on SS316L plate fabricated with single mode fiber laser [1 1673-46]

11673 1D Effect of preheating on pure copper welding by hybrid laser system with blue laser and IR laser (Best Student Poster Award) [1 1673-47] 